\title{
BUILDING AND DEVELOPING SCIENCE AND TECHNOLOGY-RELATED HUMAN RESOURCES AT UNIVERSITY OF FIRE FIGHTING AND PREVENTION IN THE NEW SITUATION
}

\section{Lich Khac Pham}

\section{Article History}

Received: June 15, 2019

Accepted: August 20, 2019

Published: September 30, 2019

\section{Keywords}

Human resource, science and technology, University of Fire Fighting and Prevention, formation, development
University of Fire Fighting and Prevention - Ministry of Public Security, Vietnam Email: phamkhaclicht34@gmail.com

\section{INTRODUCTION}

Developing science and technology-related human resources of the University of Fire Fighting and Prevention is an important content, which directly determines the improvement of high quality human resources of the college, contributing to improving its educational quality. In the past, thanks to the University's Party Committee and the School Board's close attention and direction, the quality of science and technology-related human resources has been significantly improved; however, in order to meet the goals, requirements and missions in the upcoming time, the school needs to level up the quality of the development of its science and technology-related human resources.

This article studies the situation of developing high-quality science and technology human resources and proposes some solutions for the University of Fire Fighting and Prevention to meet the requirements and missions in the new situation today.

\section{LITERATURE REVIEW}

Since the 1990s, there have been numerous scientists in the world and in Vietnam systematically researching the development of human resource of science and technology in general and at universities in particular, typically are the followings:

William, J. R. - Robert, K. P. - Maria, W. T. (2010) provides important information on a variety of trends and the promotion of human resource transformation, highlight the significance of human resource transformation, devise the plan to associate functions of human resource with the overall strategic aims and institutional success.

In the findings of his research on human resource development, Kelly, D. J. (2001) states that human resource development is one category in the overall process of human development.

Haslinda Abdullah (2009) thoroughly clarifies the concept, purposes and functions of human resource development. The above-mentioned authors have empirically and theoretically generalize the concepts and views on human resource development from different perspectives, regarding their interweaving links between the internal units and organizations and between these organizations and the external society, etc.

Cuong, D. M. and Doan, N. T. (2001) explores some issues of tertiary education; and propose some feasible solutions to promote human resources for tertiary education in support of industrialization and modernization. In the overall report named "Development of human resource of science and technology in ASEAN countries" (The National Centre of Science and Technology - 2005), the policies on exploiting, training and fostering human resource of science and technology in the ASEAN region including Singapore, Malaysia, Thailand, the Philippines and Indonesia are thoroughly summarized and analysed. Accordingly, the precious lessons for training and promoting human resource of science and technology in Vietnam are drawn.

Thanh, D. T. (2018) points out the current situation of human resource of science and technology in Vietnam in terms of quantity, quality, structure and level. Accordingly, the author proposes 5 groups of solutions to develop human resource of science and technology in Vietnam in the years to come including: Further accomplishing the regulations for science 
and technology; promoting and educating the law on science and technology; completing the policy for training and attracting scientists; creating favourable working conditions and researching facilities and equipment; ensuring the freedom of creativity in academic research and international publication of science and technology works.

Huong, D. T. T. (2018) interprets the theoretical background and international experience in developing teaching staff at private universities and colleges, analyses and assesses the current situation of developing teaching staff at private universities and colleges in Vietnam in the 1994-2016 period, and proposes basic solutions to develop teaching staff at private universities and colleges in Vietnam up to 2030.

Generally, there have been numerous works touching upon human resource development in general and the development of human resource of science and technology at universities in particular in order to meet the requirements of education and training reform. However, there are no single works systematically and thoroughly exploring the development of the human resource of science and technology at the University of Fire Fighting and Prevention.

\section{RESEARCH METHODS AND RESULTS}

\subsection{Research methods}

- Theoretical research methods: include analysis, synthesis, generalization and systematization of problems through the study of theoretical documents, monographs, scientific articles within the research scope.

- Empirical research method:

In short, studying documents and final reports related to the current scientific and technological human resources of the University of Fire Fighting and Prevention, especially related to the current situation and making comments on the construction and development of science and technology human resources of the University. In addition, the author also used methods of sociological investigation, pedagogical observation and experts.

\subsection{Research results}

3.2.1. Some theoretical issues on building and developing science and technology human resources of the University of Fire Fighting and Prevention

Developmental theory and practice in countries around the world show that human resources play a very important role in the process of growth and development in general. In the context of international economic integration, when competition is getting fiercer and fiercer, human resources play an increasingly important role. For the operation of a country in general, a locality or an organization in particular, human resources are one of the most important issues together with financial resources. The reason is that the human resource is the asset that secures and determines the management and development ability of that country, locality or organization. Universities - the basis of training high-quality human resources for the country are no exception. In order to successfully fulfill your goals and missions in education, apart from the elements and conditions of infrastructure and facilities, technical instruments, human resources of the university always play the key and decisive role.

Scientific and technological human resources in universities are those engaged in teaching, scientific research, technology transfer and educational management activities, etc. Therefore, it can be divided according to many different criteria, into many parts. Therefore, building and developing science and technology human resources to meet the training scale and strategies is an important task in all development stages of universities. Resolution of the $6^{\text {th }}$ Conference of the $11^{\text {th }}$ Central Party Committee on scientific and technological development for the cause of industrialization and modernization in the context of communism-oriented market economy and international integration determines to: "Build a science and technology personnel with high qualifications, dedication, honesty and dedication, develop strong scientific and technological organizations and teams and leading scientists". Or the Prime Minister's Decision No. 418/QD-TTg dated April 11 ${ }^{\text {th }}$, 2012, on approving the Science and Technology Development Strategy for the period of 2011-2020 also stated that: "Developing policies of training and exploitation of science and technology staff, especially young cadres with high qualifications in the fields of social sciences and humanities, natural sciences, technological science and technology. Building mechanisms for assigning potential science and technology tasks to young scientists, good student groups in key universities and key research institutes".

3.2.2. Current situation of building and developing science and technology human resources of the University of Fire Fighting and Prevention

Being aware of the guidelines of the Party and the State, in every stage of development, the University's Party Committee and the Board of Directors of the University of Fire Fighting and Prevention always pay attention to and focus on the construction and development of science and technology human resources. Specifically, it is the development of teaching staff, educational managers, multi-tasking lecturers and other scientific and technical staff. 
At the same time, it is necessary to promote scientific research and application activities on fire fighting and prevention and rescue.

In the period of 1976-1984, during the period of the Non-commissioned Police Commissioner School, many officials of the school were sent by the Ministry of Public Security's leadership to train at universities to become Associate Doctors and Doctors on fire protection in the Soviet Union. Lecturers and officers at the School of Noncommissioned Police Officers (Fire fighting and prevention Department) at that time built up the first theoretical knowledge about fire fighting and prevention operations as the basis for the vocational training system with 20 specialized textbooks, 4 university-level research projects, 5 Facuty-level research projects on fire fighting and prevention. In particular, the University's lecturers and staff successfully devised fire extinguishing powder in 1977. In 1980, the university successfully studied and installed the automatic fire alarm system which is widely used in fire fighting and prevention later.

In the period of 1984-1999, the team of fire fighting and prevention scientists continuously grew and developed together with the achievements of training and scientific research on fire fighting and prevention at the School of Fire Fighting and Prevention. Many lecturers and staffs of the Fire fighting and prevention Police Department and School were sent to attend bachelor and doctoral training programs in the Soviet Union (later as Russia). Within 15 years, the teaching staff of the University and the Department built a standard fire fighting and prevention training program for college level including 39 subjects, 29 coursebooks and teaching materials for 29 basic and specialized subjects; 134 scientific research projects with 4 ministerial-level projects, 36 institution-level projects and 94 lower level scientific projects. At the Fire Fighting and Prevention Police Department, scientific officials also contributed to the research and development of the set of 15 legal standards on fire fighting and prevention. Research achievements of lecturers and officials in this period have contributed significantly to the completion of the theoretical system of fire fighting and prevention operations, developing training programs, compiling textbooks and teaching materials on fire fighting and prevention as well as the foundation for the formulation of the Law on Fire Fighting and Prevention and regulations and standards on fire fighting and prevention.

From 2000 to the present, with the aim of promoting scientific research, improving the quality of training, internal and external teaching and working staff, the University of Fire Fighting and Prevention has focused on researching urgent issues, arising in the process of education and training, scientific research on fire prevention and rescue as well as the working practices of the Fire and Rescue Police force. Throughout 19 years of university training (20002019), the University's scientific and technological staff has successfully participated in a state-level project entitled: "Researching and manufacturing multi-purpose forest fire trucks"; managed over more than 40 ministerial-level research projects and more than 110 institution-level projects that were accepted and applied effectively in the training of the University as well as in the actual fighting of the Fire and Rescue Police force.

In particular, in recent years, the school's lecturers and educational managers have worked closely with the Vietnam Fire and Rescue Police Departments, Fire and Rescue Police Divisions, Local Police in training, scientific research, technology transfer, scientific information exchange. These activities have helped the training of human resources for fire prevention and rescue of the school step by step meet the real-life requirements, accomplish the theoretical system in close connection with the reality of combat work.

Regarding the construction and development of the scientific and technological staff, in 2000 (the first year of university-level training), the total number of lecturers and educational managers of the school was 52 . At present, this number has reached 283 (221 teachers and 62 educational managers). Regarding the quality of science and technology staff, in 2000 , there were 4 comrades with doctoral degrees and 16 comrades with master's degrees. Up to now, there have been one Professor, 6 Associate Professors, 45 PhDs and 141 masters. Regarding teaching titles, in 2000, the school had only 12 main lecturers; there have been 35 main lecturers up to now. The University's scientific and technological staff is the ones who have built 15 training programs for all levels, from vocational to undergraduate, graduate, postgraduate and directly researched, composed and compiled to build a system of textbooks and materials in support of teaching, researching and reference for the entire police force of fire fighting and prevention and rescue at present.

The training of human resources for fire fighting and prevention and rescue of The University of Fire Fighting and Prevention has achieved many achievements thanks to the serious implementation of guidelines and policies of the Party and the State by the University's Party Committee and Board of Directors, the support from the Ministry of Education and Training, the close and tight guidance of the Ministry of Public Security on the building and development of staff in general, educational management staff and lecturers in particular. That policy is concretized by projects on developing 
the contingent of cadres and lecturers in each period. On that basis, the Party Committee and the Board of Directors of the University of Fire Fighting and Prevention have proposed many specific solutions with creativity, suitable to the situations and practical conditions of each stage to build and develop teaching staff, education managers effectively.

However, the development of science and technology human resources of the school still has certain limitations compared with current requirements. Regarding the number of lecturers, educational managers, scientific and technical staff who have not met the training scale, the proportion of science and technology officials with professors, associate professors titles and doctoral degrees is still low compared with standards; the number of high-quality and specialized science and technology officials is small; the number of scientific works compared with the potential is still limited; the ability of using foreign languages of science and technology staff (especially English) is poor; employment benefits for science and technology staff are not satisfactory; conditions to ensure the improvement of the quality of scientific and technological staff are still limited, failing to meet the increasing requirements of the training of human resources for fire fighting and prevention and rescue in the context of the Industrial Revolution 4.0.

We must realize that the Industrial Revolution 4.0 has brought to all countries a smart economy. This will be a turning point, a great step forward in the history of human development. However, it also creates great challenges for many countries, many social objects, in many fields. For the field of fire prevention and rescue, the Industrial Revolution 4.0 has been promoting the process of industrialization, modernization and urbanization and increases the risks of fire and explosion. On the other hand, Industrial Revolution 4.0 can also greatly support the work of fire prevention, fighting and rescuing through the application of modern science, engineering and technology.

3.2.3. Measures to build and develop science and technology human resources of the University of Fire Fighting and Prevention in the new situation

As the only facility in the country to train human resources on fire prevention and rescue, in order to meet the requirements and tasks of science and technology in the context of Industry 4.0, in our opinion, the University should try and strive in all areas, especially, it is necessary to soon have specific strategies and solutions for the construction and development of science and technology staff; synchronously implement training, attraction, appreciation and preferential treatment policies for science and technology officials. In particular, some basic measures should be well implemented as follows:

Firstly, properly arrange and assign tasks to the University's science and technology staff, especially the lecturers and educational management staff (the core force in training and scientific research). The quality of the school's training, scientific research, the reputation and position of the school is determined to the great extent by the teaching staff and educational managers.

Accordingly, the University should pay attention to and prioritize the arrangement of staff with master's and doctoral degrees and practical experience in professional work in faculties, divisions and education management units. Annually, on the basis of staff evaluation and assessment, the units must regularly review the staff to report to propose to the competent authorities the most suitable mobilization, rotation and personnel arrangement in order to build a team of scientists of the University that is constantly developed, both in terms of quantity and quality.

Secondly, in the management and exploitation of scientific and technological staff, attention should be paid to assigning tasks in accordance with their professional competence, appropriate positions and capabilities and strengths. Attention should also be paid to checking and assessing labour productivity and regular task efficiency.

The school's science and technology staff must actively implement the Principal's regulations on assigning annual scientific research targets in order to avoid the situation where science and technology officials are not actively engaged in scientific research as currently. It should be considered a political task and regular professional task of science and technology staff. When considering staff classification and emulation in the school year, it is important to evaluate the completion and performance of tasks and annual scientific research targets and to associate responsibilities of institutional party committees and leaders with scientific research achievements of their own units.

Thirdly, it is necessary to conduct training and fostering activities in order to raise the professional qualifications, pedagogical methods, scientific research methods, working skills and methods, leadership and management experience, and soft skills, etc. for the staff of science and technology in order to maximize their capacity and intelligence to fulfill the school's training and scientific research tasks. The school needs to establish specific regulations on the timing of completing training program for scientific and technological staff.

Fourthly, it is necessary to keep well maintaining the regimes and benefits for the University's scientific and technological staff to motivate them to strive, research and contribute. The school should continue to well maintain 
and implement the payment policy, support educational and training costs; compliment and reward cadres with outstanding achievements in teaching, learning, scientific research, compiling textbooks and materials; renovate management mechanisms to find appropriate ways to encourage and motivate the staff to actively conduct scientific research. A fund for scientific research activities should be established to support scientific research activities, especially giving priority to those who have scientific papers published in prestigious international journals every year. At the same time, it is necessary to propose to the managing authorities soon to study and promulgate remuneration policies for scientific and technological staff in the People's Public Security Schools in general.

Fifthly, it is necessary to strengthen the cooperation with technical universities, scientific and technological organizations, enterprises on fire fighting and prevention in the country in order to coordinate and cooperate in researching, manufacturing tools, applying and transferring science and technology on fire prevention and rescue. Also, it is highly recommended to report actively to the Ministry of Public Security so that the University would expand international cooperation with the training facilities of advanced countries in the world to send officials abroad for professional training, improving knowledge about science and technology on fire prevention and rescue every year; organizing many international seminars on the application of science and technology in the work of fire fighting and prevention, rescue and salvage; cooperating in sponsoring projects and equipment on science and technology, on fire prevention and rescue, and salvage for the school.

\section{DISCUSSION AND CONCLUSION}

The construction and development of science and technology human resources in fire fighting and prevention in the new situation is one of the important political tasks of the school. It is required that all relevant organizations, forces, especially the leaders in the School's Party Committee and Board of Director have specific guidelines, plans, determination for effective implementation, high efficiency; have acute awareness of the above issues; apply the above measures in a flexible and creative manner suitable to the specific time, condition, circumstance, subject and each faculty and department; avoid being hasty, subjective, stamping, rigid. The mentioned measures have a close relationship, mutual interaction and impacts, affecting the construction and development of science and technology human resources of the University of Fire Fighting and Prevention.

\section{REFERENCES}

Cuong, D. M. - Doan, N. T. (2001). Human resource development for Vietnam's tertiary education. National Political Publishing House (Vietnam).

Haslinda Abdullah (2009). Definitions of HRD: Key concepts from a national and international context. European Journal of Social Sciences, 10(4), 486-495.

Huong, D. T. T. (2018). Human resource development at private universities and colleges in Vietnam at present. Doctoral thesis of Economy, Academy of Development Strategy, Ministry of Planning and Investment.

Kelly, D. J. (2001). Dual perceptions of HRD: Issues for policy: SME's, other constituencies, and the contested definitions of human resource development. Human Resource Development Outlook, Pacific Economic Cooperation Council Development Task Force 2000-2001, 53-68.

Lich, P. K. (2019). Inspection of fighting and preventing fire in Vietnam at present. Labour and Society Publishing House.

Thanh, D. T. (2018). Human resource of science and technology in Vietnam at present. Journal of Vietnam Social Science, 1, 7-13.

The Central Executive Committee (2012). Resolution No. 20-NQ/TW dated November 1, 2012 of the $6^{\text {th }}$ Congress, term XI on the development of science and technology for the cause of industrialization, modernization in the socialist-oriented market economy and international integration.

The Prime Minister (2012). Decision No. 418/QD-TTg dated April 11, 2012 on Ratification of Strategy for development of science and technology in the 2011-2020 periods.

University of Fire Fighting and Prevention (2016). Fire Prevention University - 40 years of building and developing 1976-2016. Proceeding of Scientific Conference, University of Fire Fighting and Prevention.

University of Fire Fighting and Prevention (2019). Final report of the 2018-2019 academic year and key tasks in the 2019-2020 academic year.

William, J. R., Robert, K. Pr., Maria, W. T. (2010, translated by Vu Thanh Van). Human Resource Transformation: Demonstrating Strategic Leadership in the Face of Future Trends. Publishing House of National Economic University. 